\title{
Mendudukkan status hukum asuransi syariah dalam tinjauan fuqaha kontemporer
}

\author{
Muhamad Nadratuzzaman Hosen \\ FSH UIN JAKARTA dan The Ibrabim Hosen Institute \\ Email:mnhosen@gmail.com danmnhosen@yahoo.com
}

\author{
Deden Misbahudin Muayyad \\ Fakultas Agama Islam Universitas Suryakancana Cianjur \& \\ Ibrabim Hosen Institute \\ Email:misbahudin2000@yahoo.com
}

\begin{abstract}
Insurance Law in The contemporary Islamic Jurists Reviews. The aim of this article is to explain the insurance points of view of contemporary Islamic jurists. In the classical fiqh literatures, discussion of insurance can not be found except in the book of Rad al Mubtar 'ala Dar al Mukhtar, this book is published by Ibn Abidin Hanafiyah as a Islamic Jurist. The Insurance is allowed by the majority of contemporary jurists, namely, insurance ta'awuni based on tabarru (donation), while insurance tijari is not allowed because it contains elements that are prohibited such as riba and gharar.
\end{abstract}

Tujuan dari artikel ini adalah menerangkan pandangan Fuqaha kontemporer. Dalam kitab-kitab Fiqih klasik, diskusi tentang asuransi tidak dapat ditemukan kecuali pada kitab Rad al Muhtar 'ala Dar al Mukhtar yang dikarang oleh Ibn Abidin Hanafiyah sebagai seorang ahli fiqih. Asuransi dibolehkan oleh mayoritas Fuqaha kontemporer yaitu Asuransi ta'awuni berdasarkan akad tabarru, sementara asuransi tijari tidak dibolehkan karena asuransi ini mengandung unsure riba dan gharar.

Keywords: Insurance ta'awuni; Insurance tijari; Riba and gharar

\section{Pendahuluan}

Perdebatan hukum asuransi di antara para ahli fikih dari mulai pertama dikaji sampai saat ini tidak pernah berhenti, satu pihak mengatakan boleh dan pihak yang lain melarangnya. Perdebatan panjang itu juga melebar kepada status hukum asuransi syariah atau islam, bahkan 
di Indonesia bagi sebagian kalangan baik asuransi konvensional maupun asuransi islam hukumnya haram. Setidaknya mereka mengajukan empat alasan yang menyatakan asuransi syariah hukumnya haram, pertama mereka memandang salah satu dalil yang dijadikan dasar kebolehan asuransi syariah yaitu hadits asy'ariyin tidak tepat, alasannya dalam hadits tersebut bahaya terjadi terlebih dahulu baru terjadi proses ta'awun (tolong menolong), sedang pada asuransi syariah, ta'awun dilakukan terlebih lebih dahulu padahal bahayanya belum terjadi. Kedua, mereka memandang akad tabarru dalam asuransi syariah tidak sesuai dengan pengertian hibah, karena hibah adalah memberikan kepemilikan tanpa kompensasi, sedangkan dalam asuransi syariah peserta mengharap mendapatkan kompensasi, karena menurutnya menarik kembali hibah hukumnya haram. Ketiga, menurut mereka asuransi syariah tidak sesuai dengan akad pertanggungan (dhaman) dalam fikih, alasannya pada asuransi syariah hanya ada dua pihak bukan tiga pihak sebagaimana dalam akad dhaman, dua pihak tersebut yaitu penanggung (peserta asuransi) dan pihak yang mendapat tanggungan (peserta asuransi juga), jadi dalam asuransi syariah tidak terdapat pihak ketiga yaitu pihak tertanggung. Keempat, menurut mereka dalam asuransi syariah terjadi penggabungan dua akad menjadi satu akad (multiakad), yaitu penggabungan akad hibah, akad ijarah dan akad mudharabah, padahal menurutnya multiakad telah dilarang dalam syariah.

Para imam fikih dan ulama syariah klasik tidak ada yang membahas masalah asuransi kecuali setelah paruh pertama abad $13 \mathrm{H}$ dan orang pertama yang membahasnya adalah seorang ahli fikih dari madzhab Hanafi yaitu Ibnu 'Abidin (1996: 484) dalam kitabnya Rad al Mubtar 'ala al Dar al Mukhtar. Sehingga hal tersebut menjadi salah satu alasan yang paling utama timbulnya perbedaan di antara fuqaha kontemporer tentang boleh atau tidaknya asuransi. Salah satu perbedaan yang paling menonjol adalah antara Profesor Mushtafa Zarqa seorang ahli fikih dari Syiria dan Syaikh Muhamad Abu Zahrah yaitu pada acara perayaan Ibnu Taimiyah tahun 1960 terkait dengan hukum asuransi.

Tidak ditemukannya dalil yang melarang praktek asuransi menjadi salah satu alasan pihak yang membolehkan asuransi yaitu dengan berpegang pada kaidah "hukum asal sesuatu adalah boleh kecuali ada dalil yang mengharamkannya." Pihak kedua memandang bahwa hukum asuransi adalah haram karena adanya aspek riba dan gharar. Pihak yang ketiga melarang satu jenis asuransi dan membolehkan jenis asuransi yang lain. 
Fuqaha kontemporer melakukan kajian dan bahasan mendalam terkait dengan format pengganti transaksi asuransi yang selama ini ada karena dianggap tidak sesuai dengan prinsipprinsip syariah Islam. Setelah melakukan kajian, akhirnya para ahli fikih dan ahli hukum sepakat format asuransi yang sesuai Islam adalah asuransi ta' awuni. Perusahaan asuransi Islam pertama didirikan di Khartum Sudan tahun 1979 dengan nama al-Sbirkah al-Ta'min al-Islamiyah, setelah itu pada tahun 1980 didirikan perusahaan asuransi Islam lainnya dengan nama alShirkah al-Islamiyah al-Arabiyab Li Ta'min di Jedah Arab Saudi, kemudian al-Sbirkah al-Takaful al-Islamiyah di Riyadh Arab Saudi pada tahun 1982, kemudian pada tahun 1984 di Malaysia didirikan perusahaan Takaful Islam. Pada tahun yang sama didirikan dua perusahaan asuransi yaitu Bait al-Ta'min al-Su'udi al-Tunisi di Tunisia dan Shirkah al-Barkah Li Ta'min di Sudan.

Di Indonesia fatwa tentang asuransi tertuang dengan dikeluarkannya fatwa nomor 21/ DSN-MUI/X/2001 tentang pedoman umum asuransi syariah. Beberapa poin penting fatwa tersebut adalah sebagai berikut: Pertama, Asuransi Syariah (Ta'min, Takaful atau Tadhamun) adalah usaha saling melindungi dan tolong-menolong di antara sejumlah orang/pihak melalui investasi dalam bentuk aset dan atau tabarru' yang memberikan pola pengembalian untuk menghadapi resiko tertentu melalui akad (perikatan) yang sesuai dengan syariah. Kedua, Akad yang sesuai dengan syariah yang dimaksud pada point (1) adalah yang tidak mengandung gharar (penipuan), maysir (perjudian), riba, zhulm (penganiayaan), risywah (suap), barang haram dan maksiat. Ketiga, Akad yang dilakukan antara peserta dengan perusahaan terdiri atas akad tijarah dan/atau akad tabarru'. Keempat, akad tijarah yang dimaksud dalam ayat (1) adalah mudharabah. Sedangkan akad tabarru' adalah bibah. Kelima, dalam akad tijarah (mudharabab), perusahaan bertindak sebagai mudharib (pengelola) dan peserta bertindak sebagai shabibul mal (pemegang polis). Keenam, dalam akad tabarru' (bibab), peserta memberikan hibah yang akan digunakan untuk menolong peserta lain yang terkena musibah. Sedangkan perusahaan bertindak sebagai pengelola dana hibah.

Dalam fatwa tersebut, DSN membolehkan asuransi yang berdasarkan prinsip-prinsip syariah dan membagi akad asuransi syariah menjadi dua yaitu akad tabarru yang berdasarkan tolong menolong dan akad tijarah yang berdasarkan mudharabah.

Klasifikasi asuransi syariah yang dibuat oleh DSN dalam fatwanya berbeda dengan klasifikasi dan pengertian asuransi syariah yang disepakati mayoritas para ahli fikih dunia dan 
ljthad, Jurnal Wacana Hukum Islam dan Kemanusiaan, Volume 13, No. 2, Desember 2013: 219-232

lembaga fatwa internasional. Oleh sebab itu, tulisan ini akan mengkaji pengertian, klasifikasi dan hukum asuransi menurut pandangan para ahli sehingga didapatkan tinjauan komprehensif. Selain itu, sebagai pendukung akan disajikan beberapa keputusan penting lembaga fatwa fikih dunia dan pendapat individu terkait dengan asuransi.

\section{Asuransi Ta'awuni}

Pengertian

Dalam bahasa arab padanan kata asuransi adalah al-Ta'min yang memiliki akar kata al amnu artinya aman lawan dari kata al khauf artinya takut (Mandzur: t.t.). Dalam al quran akar kata yang memiliki arti al amnu dapat ditemukan dalam beberapa ayat misalnya dalam surat al Baqarah ayat 125 dan surat Ali Imran ayat 154.

"Dan (ingatlah), ketika Kami menjadikan rumah itu (Baitullah) tempat berkumpul bagi manusia dan tempat yang aman" (al-Baqarab:125).

"Kemudian setelah kamu berdukacita, Allah menurunkan kepada kamu keamanan (berupa) kantuk. yang meliputi segolongan dari pada kamu" (Ali Imran:154).

Dalam hadits nabi yang diterima dari Ibnu Umar yang diriwayatkan oleh Ibnu Majjah: Rasululah saw bersabda:

"Mu'min adalah orang yang memberikan rasa aman kepada manusia terbadap harta dan dan jiwwanya dan Mubajir adalah orang yang hijrab dari kesalahan dan dosa".

Sedangkan menurut istilah, beberapa ahli memberikan definisi asuransi ta'awuni, yaitu sebagai berikut:

Pertama, Asuransi ta'awuni adalah akad tabaru' yang berdasarkan hukum syariah islam dalam memberikan jaminan untuk kemaslahan bagi kedua belah pihak, Di mana mu'min labu sebagai partner menerima untuk membayar setoran kerjasama, sedangkan mu'min sebagai pekerja dan sebagai wakil dari para partner serta menerima setoran kerjasama dan oleh karenanya mereka berjanji akan membayar bagi pihak yang mendapatkan manfaat sejumlah harta dengan jalan mengganti keseluruhan secara sekaligus atau secara temporal atau dengan cara membayar uang muka apabila terjadi kecelakaan yang menimpa. Sedangkan mu'min labum adalah mereka yang melakukan kerjasama yang mendapatkan keuntungan apabila ada 
dan merugi apabila terjadi dan mereka memiliki andil dalam manajemen (Muhamad, t.t.).

Kedua, Asuransi ta'awuni adalah tolong menolong di antara sekelompok orang bagi orang yang ditimpa bahaya untuk mengganti kerugian yang menimpa salahsatu dari mereka dengan jalan melakukan kesepakatan pembayaran uang sebagai pengganti apabila terjadi bahaya (kecelakaan) yang menimpa mereka (Zarqa, t.t.).

Ketiga, Asuransi ta'awuni adalah akad asuransi sekelompok orang yang karenanya mengharuskan setiap partner membayar sejumlah harta dengan jalan sumbangan untuk mengganti kemadaratan yang menimpa salahsatu di antara mereka pada saat terjadinya kecelakaan (Mulhim, 2002: 54).

Dari beberapa pengertian di atas maka asuransi ta'awuni adalah akad sumbangan di antara sekelompok orang yang bekerjasama dalam sebuah perusahaan asuransi untuk membantu apabila salahsatu pihak mendapatkan kecelakaan atau bahaya.

\section{Tujuan asuransi ta'awuni}

Tujuan asuransi ta'awuni secara umum adalah untuk saling tolong menolong di antara pihak yang melakukan kerjasama berdasarkan prinsip syariah. Sedangkan secara khusus tujuan asuransi ta'awuni adalah (Mulhim, 2002: 97). Pertama, Menciptakan rasa aman bagi nasabah. Asuransi ta'awuni memberikan ketenangan bagi nasabah dalam kegiatan sehari-harinya tanpa khawatir akan kemungkinan bahaya masa depan yang bertubi-tubi; Kedua, Media usaha halal. Di mana asuransi ta'awuni menjadi jalan yang dibolehkan untuk mencari keuntungan secara halal, hal tersebut dengan cara perusahaan asuransi bertindak sebagai wakil yang mendapatkan upah atau dengan cara mudharabah Di mana perusahaan asuransi menginvestasikan harta atau uang yang terkumpul dari setoran nasabah, keuntungan perusahaan asuransi didapatkan dari keuntungan akad mudharabah dengan pihak lain; Ketiga, Merefleksikan hukum-hukum syariah dan senantiasa memelihara kemaslahatannya pada setiap zaman dan tempat; Keempat, Ikut serta dalam membangun perekonomian dengan cara mengelola dan menginvestasikan dana nasabah asuransi; Kelima, Memelihara perekonomian dalam skala makro dari tumbuh kembangnya asuransi tijari yang mencari keuntungan sebesarbesarnya dari setoran nasabah; Sebagai partner lembaga-lembaga keuangan Islam, karena setiap lembaga keuangan membutuhkan perusahaan asuransi. 
ljtihad, Jurnal Wacana Hukum Islam dan Kemanusiaan, Volume 13, No. 2, Desember 2013: 219-232

\section{Hukum asuransi ta'awuni}

Mayoritas fuqaha kontemporer membolehkan asuransi ta'awuni yang berdasarkan tolong menolong (Qurahdaghi, 2009: 13). Ketetapan tersebut berdasarkan fatwa lembaga-lembaga fatwa baik skala lokal maupun skala internasional disamping pendapat ulama terkemuka seperti Muhamad Abu Zahrah. Berikut beberapa lembaga yang menetapkan kebolehan asuransi ta'awuni: Pertama, Tahun 1965 Majma' al Bubuts al Islamiah pada mu'tamar kedua di Kairo memutuskan bahwasanya hukum asuransi islam (syariah) yang berlandaskan ta'awun adalah boleh. Kedua, Tahun 1966 majma' al Bubuts al Islamiah mempertegas kembali keputusannya tentang bolehnya asuransi islam. Keputusan tersebut disertai dengan detail bidang asuransi yang dibolehkan, yaitu asuransi kesehatan, jaminan pengangguran, jaminan hari tua dan asuransi kecelakaan kerja. Ketiga, Tahun 1972 Nadwah al Tasyri' al Islami memutuskan akad asuransi hukumnya boleh kecuali asuransi jiwa hukumnya haram atau asuransi yang sifatnya ta'awuni hukumnya halal dan asuransi jiwa hukumnya haram. Kehalalan tersebut sifatnya temporer atau masih terbukanya pintu perbedaan seputar hukum asuransi. Keempat, Tahun 1976 al Mu'tamar al 'Alami al Awal Liliqtishad al Islami yang dilaksanakan di Makkah. Keputusan mu'tamar tersebut adalah bahwasanya asuransi tijari (konvensional) tidak sesuai dengan syariah karena karakternya bukan ta'awun (tolong menolong) serta tidak terpenuhinya ketetapan syariah yang terkait dengan hal tersebut. Selain itu, mu’tamar memberi masukan agar dibentuk sebuah komite yang terdiri dari ulama syariah dan ekonom muslim untuk merumuskan pembentukan asuransi yang bebas riba dan gharar. Kelima, Tahun 1977 Haiah Kibar al Ulama al Su'udiah mengharamkan asuransi tijari dengan semua jenisnya. Keenam, Tahun 1978 Majma' al Figh al Islami al Tabi' Lirabithah al 'Alam al Islami mengharamkan asuransi tijari dengan semua jenisnya dan membolehkan asuransi ta'awuni. Ketujuh, Tahun 1985 Majma' al Fiqh al Islami al Dauli pada mu'tamar kedua di Jedah tanggal tanggal 28 Desember memutuskan asuransi tijari adalah haram. Selain itu, dalam fatwanya juga ditetapkan bahwa asuransi dan reasuransi ta'awuni yang berdasarkan tabaru' dan ta'awun adalah boleh.

\section{Prinsip asuransi ta'awuni}

Pertama, Prinsip Tabarru'. Prinsip ini merupakan asas yang paling penting dalam asuransi ta'awuni karena sebagai pembeda dengan asuransi tijari yang didalamnya terkandung gharar. 
Dalam asuransi, baik asuransi ta'awuni maupun asuransi tijari didalamnya terdapat unsur gharar, tetapi dalam asuransi tijari gharar tersebut akan senantiasa ada karena merupakan akad pertukaran, sedangkan dalam asuransi ta'awuni gharar tersebut menjadi hilang karena merupakan akad tabarru' (Muhammad, t.th.: 6). Rasululah saw melarang praktek jual beli gharar, larangan tersebut terkait dengan jual beli dan tabarru bukan merupakan akad jual beli. Oleh sebab itu, asuransi yang dibolehkan dalam Islam adalah asuransi yang berdasarkan tolong menolong (ta'awun), dalam al Quran surat al-Maidah ayat 2 Allah berfirman: "Dan tolong-menolonglah kamu dalam (mengerjakan) kebajikan dan takwa, dan jangan tolong-menolong dalam berbuat dosa dan pelanggaran”. Dalam surat al Anfal ayat 72-73 Allah berfirman: "Sesunggubnya orang-orang yang beriman dan berhijrah serta berjïhad dengan harta dan jiwanya pada jalan Allah dan orang-orangyang memberikan tempat kediaman dan pertoIongan (kepada orang-orang mubajirin), mereka itu satu sama lain lindung-melindungi. Dan (terhadap) orang-orang yang beriman, tetapi belum berhijrah, maka tidak ada kewajiban sedikitpun atasmu melindungi mereka, sebelum mereka berbijrah. (Akan tetapi) jika mereka meminta pertolongan kepadamu dalam (urusan pembelaan) agama, maka kamu wajib memberikan pertolongan kecuali terhadap kaum yang telah ada perjanjian antara kamu dengan mereka. Dan Allah Maha Melihat apa yang kamu kerjakan. Adapun orang-orang yang kafir, sebagian mereka menjadi pelindung bagi sebagian yang lain. Jika kamu (hai para muslimin) tidak melaksanakan apa yang telah diperintabkan Allah itu, niscaya akan terjadi kekacauan di muka bumi dan kerusakan yang besar". Selain itu dalam surat At Taubah ayat 71 Allah berfirman: "Dan orang-orang yang beriman, lelaki dan perempuan, sebahagian mereka (adalah) menjadi penolong bagi sebahagian yang lain”. Tabarru' dalam akad asuransi tersebut menunjukan sikap saling tolong menolong di antara pihak yang melakukan kerjasama dalam sebuah perusahaan yaitu pada saat salah satu pihak mendapatkan musibah atau kecelakaan. Kedua, Prinsip berpegang teguh pada hukum syariat Islam. Manifestasi dari prinsip tersebut misalnya mengangkat dewan pengawas syariah yang senantiasa mengawasi dan memberi masukan dari aspek kepatuhan pada syariat islam, menginvestasikan dana nasabah pada bidang yang dibolehkan syariat Islam, memberikan pelayanan dan kerjasama kepada nasabah yang melakukan usaha halal, bekerjasama dengan perusahaan resasuransi syariah (Muhammad, t.th.: 6). Ketiga, Prinsip pembagian keuntungan asuransi. Yaitu pembagian jumlah sisa dana yang disetorkan kepada nasabah setelah dikurangi biaya penggantian resiko atau kecelakaan dan upah perusahaan asuransi (apabila perusahaan 
ljtihad, Jurnal Wacana Hukum Islam dan Kemanusiaan, Volume 13, No. 2, Desember 2013: 219-232

bertindak sebagai wakil nasabah). Keempat, Prinsip pemisahan dana nasabah dengan dana investor. Kelima, Prinsip keterbukaan atas laporan keuangan kepada nasabah.

\section{Asuransi tijari}

Pengertian

Fuqaha kontemporer mengklasifikasikan asuransi tijari sebagai asuransi konvensional. Disebut asuransi tijari karena pihak-pihak yang melakukan kesepakatan sama-sama bertujuan untuk mendapatkan keuntungan yang sebesar-besarnya (Ghamidi, 1428H: 42).

Menurut Undang-undang Nomor 2 tahun 1992 tentang usaha perasuransian, asuransi atau pertanggungan adalah perjanjian antara dua pihak atau lebih, dengan mana pihak penanggung mengikatkan diri dengan pihak tertanggung, dengan menerima premi asuransi, untuk memberikan pergantian kepada tertanggung karena kerugian, kerusakan atau kehilangan keuntungan yang diharapkan, atau tanggung jawab hukum kepada pihak ketiga yang mungkin diderita tertanggung, yang timbul dari suatu peristiwa yang tidak pasti, atau untuk pembayaran yang didasarkan atas meninggal atau hidupnya orang yang dipertanggungkan.

Menurut KUHD (Kitab Undang-undang Hukum Dagang) pasal 246 asuransi atau pertanggungan adalah suatu perjanjian, dengan mana seorang penanggung mengikatkan diri kepada seorang tertanggung dengan suatu premi untuk memberikan penggantian kepadanya karena suatu kerugian, kerusakan atau kehilangan keuntungan yang diharapkan yang mungkin akan dideritanya karena suatu peristiwa yang tak tertentu.

Berdasarkan definisi tersebut, maka dalam asuransi terkandung 4 unsur, yaitu: Pertama, Pihak tertanggung (insured) yang berjanji untuk membayar uang premi kepada pihak penanggung, sekaligus atau secara berangsur-angsur. Kedua, Pihak penanggung (insure) yang berjanji akan membayar sejumlah uang (santunan) kepada pihak tertanggung, sekaligus atau secara berangsur-angsur apabila terjadi sesuatu yang mengandung unsur tak tertentu. Ketiga, Suatu peristiwa (accident) yang tak tertentu (tidak diketahui sebelumnya). Keempat, Kepentingan (interest) yang mungkin akan mengalami kerugian karena peristiwa yang tak tertentu. 


\section{Hukum auransi tijari}

Hukum asuransi tijari menurut mayoritas fuqaha kontemporer adalah haram. Keputusan haramnya asuransi tijari tersebut tercantum dalam keputusan lembaga-lembaga fatwa yang sudah disebutkan di atas, keputusan tersebut sesuai dengan pendapatnya Ibnu Abidin. Beberapa dalil keharaman tersebut adalah (Ahmad, 1420H: 487). Pertama, Asuransi adalah riba. Yaitu pertukaran uang dengan uang (uang saat ini dengan uang yang akan datang) disertai dengan tambahan; Kedua, Asuransi adalah qimar. Karena asuransi tidak akan ada kecuali terdapat aspek bahaya dan sifat mungkin, kedua aspek tersebut adalah qimar. Oleh sebab itu, asuransi disepakati keharamannya; Ketiga, Asuransi adalah gharar. Akad asuransi adalah akad pertukaran, apabila terdapat gharar dalam akad pertukaran maka akadnya menjadi batal. Menurut Shadiq Dharir, gharar dalam akad asuransi tidaklah sedikit tetapi ghararnya banyak atau sedang, hal tersebut karena dari sebagian rukun asuransi yang utama adalah bahaya, sedangkan terjadinya bahaya sifatnya mungkin, sehingga gharar merupakan unsur pokok dalam asuransi dan merupakan karakter yang menjadi pembeda (dengan akad lainnya). Oleh sebab itu maka asuransi dilarang.

Tetapi beberapa fuqaha kontemporer membolehkan asuransi tijari seperti Mushtafa Zarqa, Abdul Wahab Khalaf, dan Ali Khafif. Sementara fuqaha yang lain mengharamkan asuransi tijari dan membolehkan asuransi ta'awuni.

Dasar kebolehan asuransi tijari menurut pendapat yang membolehkannya adalah sebagai berikut (Ahmad, 1420H: 487): Pertama, Hukum asal akad muamalat adalah boleh selama tidak adanya dalil yang mengharamkannya. Tidak ada dalil yang mengharamkan akad asuransi; Kedua, Asuransi sama seperti bolehnya akad menyewa penjaga. Kesamaan tersebut terletak pada manfaat yang didapatkan penyewa penjaga yaitu rasa aman, dalam asuransi nasabah mendapatkan rasa aman; Ketiga, Asuransi diqiyaskan dengan akad wadi'ah. Di mana pihak perusahaan mendapatkan manfaat dari setoran nasabah yang ditukar dengan jaminannya kepada nasabah, manfaat tersebut didapatkan perusahaan dari uang sewa menjaga dana yang dititipkan nasabah; Keempat, Asuransi diqiyaskan dengan akad salam. Para ulama membolehkan salam karena kebutuhan terhadap akad tersebut walaupun pada dasarnya akad tersebut terkandung unsur jahalah yaitu menjual barang yang tidak ada pada saat akad. Begitu juga dalam asuransi, banyak pihak yang membutuhkan asuransi; Kelima, Asuransi 
ljtihad, Jurnal Wacana Hukum Islam dan Kemanusiaan, Volume 13, No. 2, Desember 2013: 219-232

diqiyaskan pada akad mudharabah. Di mana nasabah memberikan dananya kepada perusahaan dan perusahaan mengusahakan dana tersebut supaya mendapat keuntungan, keuntungan tersebut untuk membayar nasabah mengalami kecelakan atau adanya bahaya; Keenam, Salah satu dalil pokok bolehnya asuransi adalah mengqiyaskannya pada akad muwalat. Perusahaan asuransi bertanggung jawab pada resiko nasabah atas cicilan yang diberikan nasabah, hal itu seperti halnya seorang muslim yang menanggung resiko pidana atas harta warisannya; Ketujuh, Asuransi diqiyaskan pada hukum 'awaqil (orang-orang berakal). Dalam hukum 'awaqil tersebut disepakati bahwa orang yang berakal menanggung diyat al Khata (denda karena bersalah) demi kemaslahatan dan saling tolong menolong. Hal tersebut berlaku juga pada akad asuransi; Kedelapan, Asuransi boleh karena berdasarkan mashlahah mursalah. Dalam asuransi terdapat kemaslahatan umum yaitu kemudahan bagi manusia dan mempersiapkan diri dari kesulitan bagi mereka; Kesembilan, Adat kebiasaan di masyarakat sudah mentolerir akad asuransi, sehingga menjadi kebiasaan yang berlaku umum. Dalam fikih, ada kebiasaan menjadi salah satu landasan penetapan hukum khususnya bagi fuqaha Hanafiyah;

Selain itu, berikut ini pendapat Mushtafa Zarqa sebagai jawaban atas beberapa pendapat terkait dengan asuransi tijari dalam buku Isa Abduh (1398H: 159-169). Pertama, Pendapat yang mengatakan bahwa asuransi adalah muqamarah. Qimar atau muqamarah adalah permainan untung-untungan serta membunuh karakter akhlak dan perbuatan manusia. Al Quran mengkategorikan qimar sebagai perangkap syaitan dan alat saling menjatuhkan di antara manusia, menciptakan permusuhan serta menumbuhkan kebencian. Selain itu, menjadikan manusia lupa mengingat Allah dan Rasul-Nya. Maka Di mana adanya qimar dalam aturan yang berdiri di atas asas yang memperbaiki akibat kesusahan yang terjadi pada manusia yang terkait dengan jiwanya, hartanya atau dalam kegiatannya. Hal tersebut dengan cara saling tolong menolong (ta'awun) pada sebagian kesusahan. Selain itu, akad asuransi memberikan rasa aman dan ketenangan kepada musta'min dari bahaya. Di mana ada ketenangan dan rasa aman bagi pihak yang melakukan qimar yang pada hakikatnya menimbulkan kesusahan. Kedua, Pendapat yang mengatakan bahwa asuransi adalah riban (taruhan/bertaruh). Jawaban dari pendapat ini sudah dijelaskan pada jawaban atas pendapat yang pertama, karena orang yang bertaruh (murabin) berdasarkan untung-untungan seperti 
halnya muqamarah. Perbedaan mendasar antara asuransi dan riban yaitu rihan tidak ada keterkaitan dalam memperbaiki bahaya kemadaratan yang akan terjadi dalam kehidupan ekonomi bagi kehidupan manusia, tidak dengan jalan tolong menolong atau dengan jalan tanggungan individu yang tidak berdasarkan tolong menolong (ghair ta'awnni). Salah satu pihak yang bertaruh tidak memberikan keamanan atau ketenangan seperti halnya akibat dalam akad asuransi. Ketiga, Pendapat yang mengatakan bahwasanya akad asuransi melampaui ketentuan Tuhan khususnya asuransi jiwa. Jawaban atas pendapat ini yaitu asuransi bukan jaminan hilangnya bahaya, karena hal tersebut diluar kuasa manusia. Seseorang tidak dapat melihat bagi dirinya sendiri suatu ketentuan atau ketetapan apapun dan seseorang tidak dapat meyakini ketetapan apapun bagi orang lain kecuali orang gila. Asuransi adalah jaminan untuk memperbaiki akibat dari bahaya yang ditimbulkan apabila memang terjadi, yaitu terjadinya perpindahan pertangguhan bahaya oleh individu yang tidak mampu kepada sekumpulan orang yang mampu. Perumpamaan tersebut seperti halnya penangkal petir yang disimpan di atas bangunan yang tinggi dan tertanam ditanah yang dalam, penangkal petir tersebut dibuat oleh insinyur bukan untuk mencegah terjadinya petir karena tidak punya kuasa atas hal tersebut, tetapi sebagai alat untuk memindahkan kilat petir yang dapat menyebabkan hubungan arus pendek. Inilah logika sederhana atas asuransi, apakah hal tersebut disebut melampaui ketetapan Allah swt atau hal tersebut pada hakikatnya adalah melaksanakan perintah Allah sebagaimana firman Allah dalam surat al-Maidah ayat 2; "Dan tolong-menolonglab kamu dalam (mengerjakan) kebajikan dan takwa, dan jangan tolong-menolong dalam berbuat dosa dan pelanggaran". Lebih dari itu al Quran menyebut kematian sebagai musibah atau bahaya yaitu dalam surat al Maidah ayat 106; “...lalu kamu ditimpa bahaya kematian", maka hal tersebut pantas apabila saling tolong menolong dalam memperbaiki dampak bahaya yang ditimbulkan. Keempat, Pendapat yang mengatakan bahwa dalam asuransi terkandung gharar. Jawaban atas pendapat ini adalah dalam akad asuransi terdapat pertukaran hasil yang bisa terwujud. Adanya sifat mungkin dalam asuransi hanya terkait dengan mu'min saja yaitu apabila terjadi kecelakaan maka harus dibayar dan apabila tidak terjadi kecelakaan maka tidak perlu membayar. Tetapi sifat mungkin ini tidak terkait dengan keseluruhan akad asuransi dan keseluruhan sistem asuransi. Adapun bagi musta'min (nasabah) sifat kemungkinannya tidak ada karena adanya pertukaran hakiki pada asuransi dengan setoran tetap, yaitu antara setoran yang dibayarkan musta'min dengan rasa 
ljtihad, Jurnal Wacana Hukum Islam dan Kemanusiaan, Volume 13, No. 2, Desember 2013: 219-232

aman yang didapatkan. Keamanaan dan ketenangan yang diberikan mu'min merupakan timbal balik dari cicilan musta'min, hal tersebut adalah pertukaran hakiki. Para fuqaha membolehkan akad kafalah walaupun didalamnya terdapat sifat mungkin, yaitu sahnya akad kafalah walaupun makful bihnya majhul (tidak diketahui). Apabila ada pertanyaan bukankah rasa aman bukan barang yang bisa dijadikan obyek pertukaran? Sesungguhnya rasa aman merupakan kebutuhan terbesar dalam hidup manusia seperti firman Allah dalam surat al Quraisy ayat 3-4 "Maka hendaklah mereka menyembah Tuban Pemilik rumah ini (Ka'bah). Yang telab memberi makanan kepada mereka untuk menghilangkan lapar dan mengamankan mereka dari ketakutan". Kita juga akan menemukan dalam akad yang disepakti kebolehannya oleh fuqaha madzhab yaitu akad menyewa penjaga. Dalam akad tersebut tujuan penyewa adalah mendapatkan keamanan, hal tersebut sama halnya dengan asuransi, setoran yang diberikan oleh nasabah kepada perusahaan asuransi bertujuan untuk mendapatkan rasa aman dari resiko kecelakaan atau bahaya. Kelima, Pendapat yang mengatakan bahwa dalam asuransi terkandung jahalah, karena musta'min tidak tahu jumlah cicilan yang harus dibayar sampai dia meninggal. Karena jahalah menjadikan tidak sahnya akad syariah. Jawaban atas pendapat tersebut adalah fuqaha Hanafiyah mengajukan analisa secara terperinci terkait dengan bahasan jahalah dan mereka membedakan akibat yang ditimbulkan dari jahalah berdasarkan jenisnya, mereka tidak memberi hukum batal atau rusak secara mutlak apabila dalam suatu akad terdapat jahalah seperti halnya madzhab yang lain, tetapi mereka membedakan antara jahalah yang mengakibatkan terhalangnya pelaksanaan akad dan jahalah yang tidak mengakibatkan terhalangnya pelaksanaan akad. Jenis pertama yaitu jahalah yang mengakibatkan terhalangnya pelaksanaan akad adalah sesuatu yang menghalangi sahnya akad, seperti jika seseorang berkata kepada yang lain "saya jual sesuatu kepada anda" atau "saya sewakan sesuatu kepada anda dengan barga sekian", sesuatu tersebut tidak ditentukan atau bisa juga ditentukan tetapi harga atau sewanya tidak ditentukan, bagi sebagian pihak lain akad tersebut diterima walaupun terdapat jahalah. Akad dan contoh tersebut semuanya tidak sah karena jahalah tersebut dapat dijadikan alasan bagi masing-masing pihak, pada kasus tersebut hakim tidak bisa memvonis karena penjual atau yang menyewakan menginginkan menyerahkan seminimal mungkin dan mengambil semaksimal mungkin dengan alasan tidak adanya ketentuan, dilain pihak pembeli atau penyewa menginginkan mengambil semaksimal mungkin dan menyerahkan seminimal 
mungkin dengan alasan tidak adanya ketentuan, sehingga jabalah tersebut menjadi alasan yang bobotnya sama bagi masing-masing pihak, maka akadnya menjadi tidak sah. Adapun jenis kedua yaitu jahalah yang tidak mengakibatkan terhalangnya pelaksanaan akad adalah jahalah yang tidak berdampak pada akad, seperti jika seseorang menyerahkan semua yang menjadi haknya kepada orang lain (dan masing-masing pihak tidak mengetahui jumlah dan jenisnya), hal tersebut sah dan semua hak tersebut menjadi jatuh. Ini adalah pandangan Hanafiyah terkait dengan jahalah dalam akad. Pelaksanaan prinsip tersebut dalam cicilan asuransi jiwa adalah jabalab dari jenis yang dibolehkan, karena jumlah setiap cicilan adalah jumlah yang diketahui, adapun jahalah dalam jumlah seluruh cicilan dibolehkan sepanjang pihak asuransi berjanji apabila nasabah meninggal dunia akan membayar sejumlah yang telah disepakati kepada keluarganya, tanpa melihat jumlah cicilan yang sudah dibayarkan banyak atau sedikit. Hal tersebut didasarkan pada pendapat Hanafiyah yang berpendapat sahnya jual beli barang dalam kotak yang terkunci tanpa diketahui jenis dan jumlahnya dengan harga tertentu, Hanafiyah berpendapat walaupun akad tersebut terdapat jahalah tetapi tidak menghalangi pelaksanaan akad berdasarkan kesepakatan dua belah pihak.

\section{Penutup}

Fuqaha kontemporer membagi asuransi menjadi dua yaitu asuransi ta'awuni atau tabarru yang landasannya adalah tolong menolong dan asuransi tijari yang landasannya adalah bisnis atau profit oriented. Sebagian fuqaha membolehkan asuransi tijari dan sebagian yang lain mengharamkannya. Tetapi mayoritas ulama fikih kontemporer sepakat bahwa asuransi ta'awuni atau tabarru' adalah boleh.

Menurut penulis, asuransi boleh dengan catatan perusahaan asuransi syariah harus selalu memperhatikan prinsip-prinsip syariah sehingga terhindar dari praktek asuransi tijari yang diharamkan oleh mayoritas fuqaha. Efektifitas ketaatan tersebut dimanifestasikan dengan berfungsinya dewan pengawas syariah, kelurusan niat manajemen perusahaan asuransi dan cara pandang nasabah terhadap asuransi yang beroperasi berdasarkan prinsip syariah. 
ljtihad, Jurnal Wacana Hukum Islam dan Kemanusiaan, Volume 13, No. 2, Desember 2013: 219-232

\section{Daftar pustaka}

Abduh, Isa. al-Ta'min Bain al-Hil wa al-Tạ̣rim. Kairo: Dār al I'tisham, 1398 H.

Ahmad, Usman Baker. Waqäi' Nadwah al-Tațiqath al-Iqtișädiyah al-Muäshirah. Jedah: Maktabah Malik Fahad, 1420 H.

Ghamidi, al-Abdul Aziz. I'ádah al-Ta'mīn wa al-Badil al-Islami. Riyadh: Majalah al 'Arabiyah Lidirasat al Amniyah wa al Tadrib, $1428 \mathrm{H}$.

Ibnu Mandzur. Lisan al-Arab. Beirut: Dār al Șadir, t.th.

Muhamad, Hamid Hasan. "Al-Ta'mīn al-Ta'-awuni al-Aḥkam wa al-Dhawābit al-Shar'iyah", paper yang diterbitkan oleh Majma' al Fiqh al Islami al Dauli pada muktamar kedua puluh.

Mulhim, Ahmad Salim. al-Ta'min al-Islämi, Där al I'lam, 2002.

Al-Qurahdaghi, Ali Muhyidin. al-Ta'min al-Ta'awnnī Mabiyatubu wa Dawabitubu wa Mu'awiqatubu, Riyadh, Paper pada Multaqa al Ta'min al Ta'awuni Tahun 2009.

Salus, Ali Ahmad, al-Iqtisāed al-Islämi wa al-Qadhaya al-Fiqhiyah al-Mu'ashirah, Doha: Dar alTsaqofah, 1996.

Zarqa, Mushtafa, Nizam al-Ta’mīn, Amman: Muasasah al Risalah, t.th. 